\title{
Speed of Use of Social Media as an Antecedent of Speed of Business Internationalization
}

\author{
Josep Rialp-Criado, Universitat Autònoma de Barcelona, Bellaterra, Spain \\ iD https://orcid.org/0000-0002-0656-1592 \\ María-del-Carmen Alarcón-del-Amo, Universidad de Murcia, Murcia, Spain \\ iD https://orcid.org/0000-0002-5195-3923
}

Alex Rialp, Universitat Autònoma de Barcelona, Bellaterra, Spain \& Norwegian University of Science and Technology, Trondheim, Norway

\begin{abstract}
Despite various advances in international business and entrepreneurship literatures and increasing interest in speed of internationalization mainly among international entrepreneurship scholars, the relationship between the use of social media and the internationalization speed of the firm remains poorly investigated. This article presents the reflective construct "speed of use of social media" and proves its positive effect on the third order formative construct "speed of internationalization." Furthermore, using multi-group analysis, the article demonstrates that this effect is moderated by the industry where the company performs (business-to-customer vs. business-to-business) and its export intensity, but not by the size of the firm. The results obtained open an interesting area for further research in the role of Web 2.0 and social networking in future knowledge management systems of international new ventures companies.
\end{abstract}

\section{KEYWORDS}

Multi-Group Analysis, PLS-SEM, Social Media, Speed Of Internationalization

\section{INTRODUCTION}

Globalization and emerging markets are offering amazing opportunities to new and old companies that move faster to foreign markets. For example, the world's best startup examples like Uber, AirBnB and BlaBlaCar are actually looking to be the first at customizing their business models to suit requirements of various APAC and MEA markets. Airbnb, for example, leveraged the advantages of being a first mover to the European and Asian Markets against its counterpart Wimdu. Late entrants such as Expedia and Amazon faced difficulty in instituting themselves in the region (and this came at a higher cost as well). But the speed of internationalization is not only relevant for startups, GarcíaCarcía, García-Canal and Guillén (2017) found that firms from the 'old' Europe can also keep up with new trends in internationalization and profit from speeding their internationalization process, thus providing some hope to the managers of established multinationals from developed economies whose global leadership has been challenged by newcomers to the international scene.

In fact, different studies have focused on the speed of internationalization concept in the literature (Jones, Coviello and Tang 2011; Johanson and Vahlne 1977; Rialp, Rialp and Knight 2005; Zhang, 
Sarker, and Sarker 2013; Casillas and Acedo 2013; Casillas and Moreno-Menéndez 2014). In this sense, it is possible find studies relating speed of internationalization to investment in technology (Saarenketo, Puumalainen, Kylaheiko, and Kuivalainen, 2008); to technology-intensive sectors (Mohr and Batsakis 2014); and also, importantly, studies focused on the effect of speed of internationalization on performance (Hilmersson and Johanson 2016). However, as recognized by Mohr and Batsakis (2014 p. 601), "research on the speed with which firms expand their operations internationally is scarce at best, in particular, when compared to other questions related to international expansion such as, for example, entry mode choice".

In this sense, the possible antecedents of speed of internationalization, for example the relationship between information and communication technologies (ICTs) in general, and social media (SM) in particular, and internationalization speed remains poorly investigated (Morgan-Thomas and Jones 2009). Durkin, McGowan and McKeown (2013, p. 720) point out: "there is a deficit in the research with respect to a more strategic consideration of how SM can add value to the customer-SME relationships".

Therefore, this article attempts to delineate the role of SM usage in the internationalization process of firms and elaborate on how the speed of use of SM may accelerate the speed of internationalization. Internationalization has much of market relationships, as involve entering to new markets. Musteen, Francis and Datta (2010) indicate that firms sharing a common language with their international ties are able to internationalize faster than firms that do not share a common language. Therefore, the faster a company uses social networks sites, the faster the company can obtain a common language with their international ties that, at the same time, allow the company to develop a faster internationalization process. In this sense, according to Ibeh and Kasem (2011), social and business networks were found to be important in explaining the internationalization speed, but social ties seemed more influential at initial stages of the process.

Furthermore, brands can exploit the potential of social media by establishing an online brand community based on a structured set of social relations among admirers of a brand. Kananukul, Jung and Watchravesringkan (2015) prove that brand trustworthiness is formed through consumer's trust toward social network sites, brand trust induces a high degree of brand loyalty and those individuals with higher brand loyalty are likely to purchase the brand's products more frequently as well as in a higher volume.

Therefore, the firms' possession of intangible resources and assets (e.g. brand trustworthiness), acquired first for those firms that faster use social sites, explain the speed with which firms expand their international operation. Therefore, as previous authors have done (Mohr and Batsakis 2014), we draw on the resource- and knowledge based views (RBV/KBV) of the firm to identify another intangible resource that explains speed of internationalization.

It is not a surprise that any activity related to market relationship will be positively related to internationalization process. If this issue is accepted, higher speed of market relation activities should positively influence internationalization speed; in other words: if the company is faster using SM, it will increase the speed of internationalization (what does not mean that if the company does not use SM cannot be fast in its internationalization speed: the company would be faster in its internationalization process if its speed of use of SM was higher). The fact that SM are borderless, allows reinforce the idea that the speed of internationalization can be faster. Thus, this research proposes a model that introduces the direct effect of the speed of use of SM on the speed of internationalization and the moderating effect of industry, size and export intensity of the firm on the proposed relationship.

The remainder of this article is organized as follows: first it provides a brief overview of literature on speed of internationalization and SM. Subsequently, it develops the model and the hypothesis that explicates the relationships between the speed of use of SM and internationalization speed and shows how such relationship may be moderated by different characteristics of the firm. Then the basis of the empirical investigation is explained and finally, it concludes by discussing the theoretical and practical implications of the arguments and how they enhance the current understanding of international entrepreneurship. 


\section{BACKGROUND}

\section{Speed of Internationalization}

Chetty, Johanson and Martín (2014) refer to physics to conceptualize the concept of speed of internationalization. As they mention, "speed" is defined and measured as "distance divided by time" in physics; therefore, they consider that speed has two components: time and distance and define speed of internationalization as "a relationship between the internationalization distance covered and the time passed to reach this" (p. 640). So, adopting this formula, it could be possible to assume, for example, that the number of foreign markets where a firm initiates its operations could be a proxy of the "distance" covered, while time could be the difference between the current year (2015) and its year of inception. This physic analogy could be generalized for conceptualizing other theoretical constructs related to speed. In fact, Chetty et al. (2014) refer to the internationalization process literature for conceptualizing internationalization distance, and found that the concept could be related to the firm's knowledge (mostly experiential) and to the firm's commitment to international markets.

We agree with Chetty et al. (2014) when they argue that "experience gained from international activities during a specific time period can be assumed to correspond to the firm's speed of international learning" (p.640), and experience is gained by conducting business in different markets: the diversity of markets' conditions allow firms to learn more in comparison with a situation where the conditions of the international markets were the same. Likewise, the potential for repetition is an intrinsic component of learning. Consequently, the more experiential knowledge gained during a specific period of time, the bigger the contribution to the speed of internationalization. On the other hand, international commitment supposes that firms invest resources in foreign markets instead of investing in the domestic one (Johanson and Vahlne 1977); therefore, international commitment reflects the firm's dependence on foreign markets. Although the commitment concept in the international business literature has been addressed from different approaches (da Rocha, Cotta del Mello, Pacheco and de Abreu Farias 2012), it is possible to identify a common point of view: the loose of value of committed resources when the firm moves to other markets.

Chetty et al. (2014) consider that "speed of committing internationally relates to international commitment and time" (p. 641), for instance, the more employees devoted to the international operations during a specific period of time or the more resources are committed to legal entities in international markets, the bigger the international commitment. Therefore, the larger the magnitude of resources committed internationally during a specific period of time the higher the speed of internationalization.

\section{Speed of Implementation of Social Media}

The term "Social Media" (SM) has been defined by the literature as "a group of Internet-based applications that build on the ideological and technological foundations of Web 2.0, and that allow for the creation and exchange of user-generated content" (Kaplan and Haenlein 2010, p. 61). SM comprise both the conduits and the content disseminated through interactions between individuals and organizations (Kietzman, Hermkens, McCarthy and Silvestre 2011). These technologies have the potential to provide greater access to customer information through customer-customer interactions or through company-customer interactions (Agnihotri, Kothandaraman, Kashyap and Singh 2012).

To measure "speed of use of SM" the research draws on the physics analogy employed previously by Chetty et al. (2014) for defining the concept of speed of internationalization. In this research, we define speed of use of SM as the relationship between the SM use distance and the time passed to reach this. Therefore, it is needed to identify the two components of the formula: distance covered and time, and then it can define speed of use of SM as a relationship between the SM use distance covered and the time passed to reach this distance.

Considering the previous literature on SM, the conceptualization of SM use distance could be related to the regular use of SM applications in the operations and transactions of the company. 
Regarding the time component, this research considers the number of years the firm has been operating since the existence of SM technologies. According to Michaelidou, Siamagka and Christodoulides (2011), a time-line based on Google trends shows a growing interest in SM since 2004. In addition, O'Reilly and Musser (2007) explain that in 2004 they realized that the Web was on the cusp of a new era, the Web 2.0. Therefore, 2004 can be considered the year when SM tools started being used by companies. So, the number of years a firm has been operating since 2004 could be considered the time dimension.

\section{THEORETICAL MODEL AND HYPOTHESIS}

The use of SM by international new ventures can potentially accelerate their internationalization due to (1) the pursuit of high, value-added IT applications to maintain a competitive edge; (2) the reduction in the costs of communicating with foreign customers/suppliers and of gathering information about foreign competitors; and (3) the support/enhancement of distinctive competencies and skills in other business functions (Zhang et al. 2013).

Pezderka et al. (2012, p. 9) assert that "those companies that develop superior capabilities in terms of communication with customers, relationship-building, reaching potential customers, bypassing costly physical presence in foreign markets, market research, being a front-runner in employing advanced export management technology, and cost reduction through Internet deployment, will experience enhanced export performance". Therefore, along with the emergence, further development and deployment of SM technologies, companies now have a greater ability than ever to take advantage of international market-growth opportunities (Mathews, Healy and Wickramasekera 2012) and therefore, the adoption and current use of SM may have unique implications for increasing the speed and benefits of internationalization (Okazaki and Taylor 2013).

Musteen et al. (2010) developed some hypotheses relating the structural, cognitive and relational aspects of the international network of SME CEOs to two internationalization outcomes - speed and performance drawing on social capital theory and the international entrepreneurship literature. Their findings indicate that firms sharing a common language with their international ties are able to internationalize faster than firms that do not share a common language. Therefore, the faster a company uses social networks sites, the faster will obtain a common language with their international ties that, at the same time, allow the company to develop a faster internationalization process. Ibeh and Kasem (2011) also remark the importance of the relational perspective in explaining the internationalization speed. According to these authors, both social and business networks were found to be important, but social ties seemed more influential at initial stages of the process.

Furthermore, social network sites (e.g. LinkedIn) enable users to connect and stay in touch with other people (Phan, Thomas and Heine 2011). Brands can exploit the potential of social media by establishing an online brand community, which is a specialized, non-geographically bound community, based on a structured set of social relations among admirers of a brand. Kananukul et al. (2015) prove that brand trustworthiness is formed through consumer's trust toward social network sites, brand trust induces a high degree of brand loyalty and those individuals with higher brand loyalty are likely to purchase the brand's products more frequently as well as in a higher volume. Accordingly, it can be expected that:

Hypothesis One: The higher the speed of use of social media, the higher the speed of internationalization of exporting firms.

The moderator variables used for this study are as follows: industry type, firm size and export intensity of the firm. Different papers that have analysed speed of internationalization have considered size as a control variable (Acedo and Jones 2007; Chetty et al. 2014; Hutzschenreuter, Kleindienst, 
Guenther and Hammes 2016; Luo, Zhao and Du 2005; Mohr and Batsakis 2017). In this sense, it is possible to find specialized literature where speed of internationalization is considered as an explanatory of firm performance (Hilmersson and Johanson 2016) where size and industry have also played the role of controls. Likewise, other papers that have been focused on explaining speed of internationalization and have considered, in line with the current research, possible determinants (for example, the learning acquired in the course of past internationalization activities (Casillas and Moreno-Menendez 2014); firms' possession of intangible resources, in particular, intangible assets (e.g. brand value) and different types of experiential knowledge of international operations (Mohr and Batsakis 2014); and/or individual-level and company-level antecedents, including propensity to act, risk tolerance, company-level organization of knowledge, ability to forge company-level consensus, and company-level responsiveness (Li, Qian and Qian 2015); have also considered size and industry as control variables.

Perrigot, Kacher, Basset and Clique (2012) analyzed the relationship between the presence of the company in SM and the industry where the company operated, finding a significant relationship. The industry type in which a business operates may influence the adoption of information system (IS) innovations, including Internet and e-business technologies (Levenburg et al. 2006); although other authors do not confirm this view (Teo 2007). In this sense, Swani, Brow and Milne (2014, p. 873) recognize that "social media research and stories of its effectiveness mainly focus on businessto-consumer (B2C) examples in which social media leads to increased brand awareness, loyalty, engagement, and sales (e.g., Kumar and Mirchandani 2012; Rapp, Beitelspacher, Grewal and Hughes 2013; Taylor, Lewin and Strutton 2011; Wiersema 2013)". From the point of view of these authors, B2B marketers seem hesitant to adopt social media marketing strategies. They refer to Giamanco and Gregoire (2012) to point out that only 5\% of B2B marketers cite social media marketing as a welloptimized part of their marketing mix, $17 \%$ do not use social media at all, and $58 \%$ consider themselves in the initial stages of developing their social media strategies. Taking into account the consideration done for some authors that service businesses are more predisposed towards using the Internet for business activities than manufacturing enterprises (Goode and Stevens 2000), the relationship among speed of use of SM and speed of internationalization could be moderated differentiating between B2B and B2C companies. The need for B2C firms to connect with international customers, and every time more frequently, could suppose that these companies with a higher speed of use of SM could internationalize faster. Therefore, it can be hypothesized that:

Hypothesis Two: The higher the speed of use of social media, the higher the speed of internationalization of B2C than B2B.

Some authors verified that the size of the firm has a positive direct influence on export performance (Calof 1994; Majocchi et al. 2005; Williams 2011). For example, Bonaccorsi (1992) established that small firms export a lower share of their sales because of limited resources, lack of scale economies and high risk perception in international activity. Majocchi et al. (2005) find a highly significant relationship between firm size and export intensity, when size is measured by number of employees. Nazar and Saleem (2009) conclude that firm size has positive effect on export performance if measured in terms of total sales and has negative effects are found on export profits if measured by number of employees a firm have. However, the impact of size on exports is not free of controversy in the literature. Smaller firms are also seen by the academic literature as quicker and more flexible than the larger ones due to structural simplicity, and therefore efficient adaptation can provide them a competitive advantage in responding to the specific requirements of foreign buyers when export relation size increases (Verwaal and Donkers 2002). That is the reason why some authors, as Moen (1999) and Pla-Barber and Alegre (2007), did not find a significant relation between seize and export: Moen (1999) find that firm size and export intensity is not significantly related; while Pla-Barber and Alegre (2007) find that firm size is not a preponderant factor for the internationalization of biotech 
firms and mention that prior research had generally focused on manufacturing industries without taking into account the implications of dealing with heterogeneous technology profiles.

On the other hand, firm size has been found to positively predict the adoption of IS (Teo 2007; Huang et al. 2008); although some researchers (e.g. Goode and Stevens 2000) have failed to confirm this relationship. In this sense, Lorenzo-Romero et al. (2013) in their study of the use of SM as a marketing strategy by retailers, did not find many differences between large, medium, and small companies in the use of SM tools. Attending previous literature, we based on the assumption that for larger firms, less flexible than smaller ones, a higher speed of use of SM could benefit a faster internationalization. Therefore, we establish the following hypotehsis:

Hypothesis Three: The higher the speed of use of social media, the higher the speed of internationalization of larger firms than smaller firms.

Finally, it can be posited that the higher the export intensity of the firm, the higher the dependence of the firm of the international markets and its experiential knowledge obtained about them. The export intensity is characterized by a considerable amount of uncertainty, which stems from the lack of knowledge about foreign markets. That is the reason why managers need to develop their international contacts to achieve market entry to the leading markets. Just a passive following strategy will downsize the market opportunities and if the internationalization happens after all, it will take place in the economies with lower economic potential (Ojala 2009). On the other hand, and as it has been already mentioned, firms sharing a common language benefit from networking and internationalize faster than the ones that do not share common language (Musteen et al. 2010). Therefore, for those firms depending more on foreign markets, the higher speed of use of SM could facilitate a higher speed of internationalization. The knowledge needed to compete in foreign markets can be acquired through experience from practical operations abroad but nowadays it could also be obtained using SM. A firm using SM tools for connecting with its foreign customers could better know the differences in environmental conditions and is more likely to select the most attractive markets and adapt the marketing strategy to accommodate the specific needs of those markets abroad (Cavusgil and Zou 1994).

Hypothesis Four: The higher the speed of use of social media, the higher the speed of internationalization of high-export intensity firms than low-export intensity firms.

As it has been seen, the variables considered here as moderators are among the most frequently considered as possible firm-level determinants of export performance (Grandinetti and Mason 2012). For instance, the emergence of the size of the firm as a key determinant is not a surprise, as its relationship with export performance has been one of the most extensively studied in the export marketing literature (Moen 1999). However, no significant relationship was found between the size of the firm and export performance in some cases (Moen 1999; Contractor et al. 2005). Thus, the connection between firm size and performance is still a controversial issue (Brouthers and Nakos 2005). Studies on the relationship between firm size and internationalization highlight the fact that small size does not constitute per se a barrier to exporting and that, despite having fewer resources, SMEs can successfully enter foreign markets and achieve a high level of exports. This characteristic of "mixing empirical results" is also related to other determinants of export performance. In this sense, several empirical studies report a significant positive relationship between experience in foreign markets and performance (Lado et al. 2004), whereas other studies have suggested that international experience is negatively related to export performance (Brouthers and Nakos 2005).

Figure 1 shows the proposed model, in which the relationships that will be tested in the measurement and structural model, and the moderating effects, are included. 


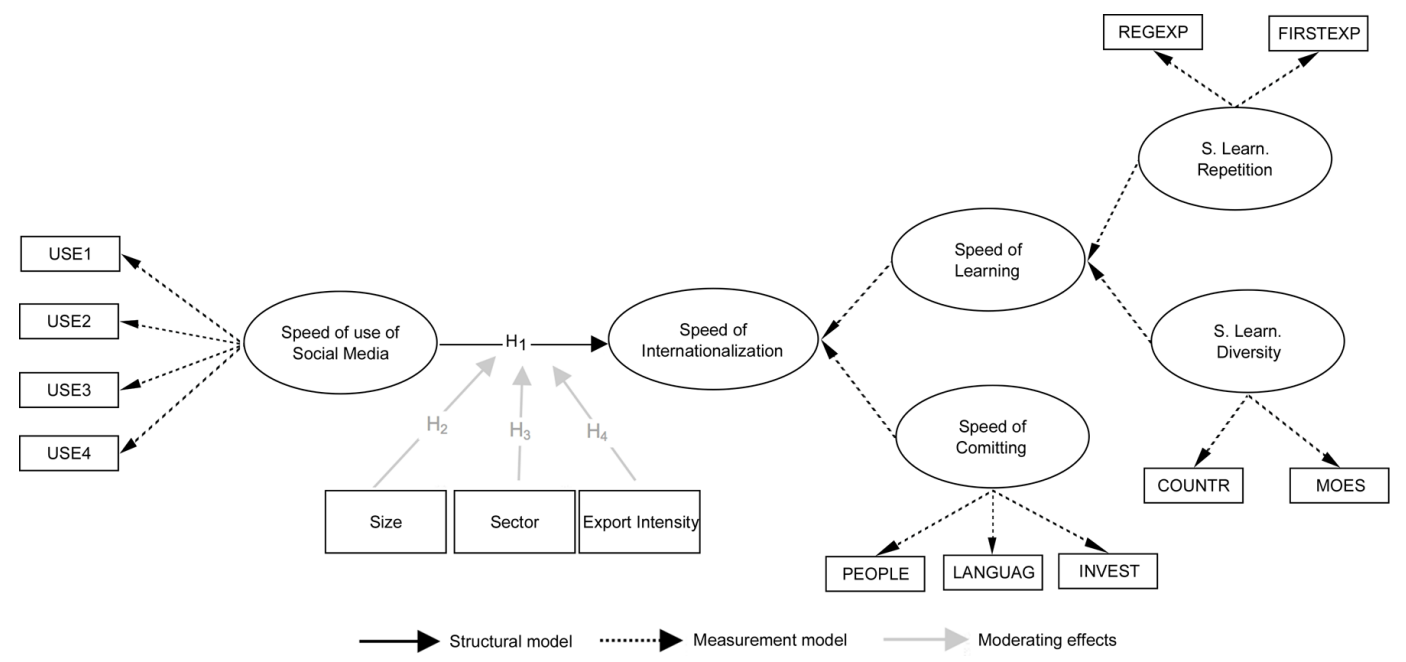

\section{METHODOLOGY}

\section{Sample and Procedure}

An online questionnaire to multi-industry sample of Spanish exporting firms was used as method of data collection in December 2014. A multiindustry sample enlarges the observed variance and emphasizes the generalization of the findings (Morgan, Kaleka, \& Katsikeas, 2004; Navarro-García, Arenas-Gaitán, \& Rondán-Cataluña, 2014).

Given that the study's unit of analysis was at the organization level, and the research focuses mainly on the internationalization process of the company and the use of SM, international and general manager/s in charge of the firm's foreign business activity were contacted. The final sample was obtained from the market research company GMI based on the ICEX (Spanish Institute for Foreign Trade) database of exporters. The non-probability method by quota sampling was used to ensure that the sample is representative of the Spanish exporting companies' population with regard to region of location. Maintaining sectorial proportionality, 1100 managers in charge of exports (i.e. export managers) received the questionnaire, and 337 fully valid ones were returned.

To analyse the possible non-response bias, we compared the number of times the Web page with the survey was requested with the number of completed research responses actually received, so we could make a reasonable estimation of active refusals: the web page was requested more than 970 times and the number of completed research responses was 337, which represents a $34 \%$ rate of non-refusal —overcoming the range of 15-20\% mentioned by Menon, Bharadwaj and Howell (1996) - . Unfortunately, we could not compute differences in key variables among those answering the survey and those that did not because the directory where the contact information was found did not provide us with other types of information.

Likewise, to analyse the possible differences between earlier and late respondents (regarding those who answered first to the questionnaire and those who answered after the first and second re-call), we ran bivariate analysis and we did not find any significant differences in their responses.

The final sample consisted of 337 exporters. These companies are, in average, 52 years old, they have been regular exporters for almost 19 years - a similar percentage to the one obtained by Navarro-García et al. (2014) - , their average level of export intensity is $57 \%$, and the number of exporting countries, in average, is 16 (being the maximum number of exporting countries by a firm 160). Most firms are small and medium-sized (67.1\%), with the mean number of employees 
Table 1. Demographic information of the sample

\begin{tabular}{|l|l|l|}
\hline \multicolumn{1}{|c|}{ Sample size } & \multicolumn{2}{c|}{337} \\
\hline Age & 52 years old (average) \\
\hline Time being regular exporter & 19 years (average) \\
\hline Export intensity & $57 \%$ (average) \\
\hline Number of exporting countries & 16 (average) \\
\hline Size & Small and Medium size $(67.1 \%)$ & 142.7 (average number of employees) \\
\hline & Big size companies $(32.9 \%)$ & 9035 (average number of employees) \\
\hline Industry & B2B & $58.8 \%$ \\
\hline & B2C & $41.2 \%$ \\
\hline
\end{tabular}

being 142.7. The big size companies (32.9\%) have a mean number of employees of 9,035.1. The $58.8 \%$ of the sample are B2B and the $41.2 \%$ are B2C companies. We defined whether a given firm can be classified as SMEs or a large firm following OECD definition (OECD 2018); and we follow Horjmose, Brammer and Millingotn (2012) to establish if a firm was active in a business to business or a business to consumer sector (as these authors we based on the firm's primary activity as provided by CNAE, more precisely, we used the 4 digit CNAE code that characterized a firm's primary activity to allocate firms to the $\mathrm{B} 2 \mathrm{~B}$ or $\mathrm{B} 2 \mathrm{C}$ sectors).

\section{Measures}

Most of the measures used in the study were taken from previously validated sources, specifically those variables used to measure the third-order construct "Speed of Internationalization". In fact, following Chetty et al. (2014), "speed of internationalization" will be conceptualized as a formative higher-order construct created by two dimensions in this research: speed of international learning and speed of committing internationally. The construct "speed of international learning" is operationalized as a reflective first-order, formative second-order construct (i.e., a 'type II' construct according to the alternative second-order factor specifications provided by Jarvis et al. 2003), that is, formed by two constructs with reflective indicators: "Speed of learning from repetition of international activities' and 'speed of learning from diversity of international activities". The first one captures the speed of the time-based dimension of learning, i.e., learning by repetition and is reflected in indicators such as the speed of obtaining the first export order and achieving regular exports. The second one is reflected in indicators such as the speed of the geographic scope and of diversity of entry modes used in international operations. That is, the 'rate' at which the firm has entered foreign countries and used several different entry modes.

Regarding the measurement of "speed of committing internationally", this is expected to be reflected in indicators capturing the speed and degree of integration and specialization of the resources and the amount of resources (Johanson and Vahlne 1977). In other words, this research measures the speed at which the firm commits specific resources with indicators such as the "speed of committing staff in international activities" (e.g., number of full time employees currently active in international activities/number of years operating) and the "speed of using a firm's foreign language skills", and the speed at which the firm invests significant resources internationally or "speed of entry modes commitment".

At the beginning of the questionnaire, we included a brief description about the objective of the research and definition of Social Media. In this research, we consider Social Media as interactive and user-generated content applications used by customers for communication and for the creation, 
editing, and dissemination of content. Social Media include blogs, social networks, customer forums, content aggregators, wikis, etc. (Constantinides and Fountain 2008).

As it has been mentioned in the section "Speed of implementation of Social Media", in this research we define speed of use of SM as the relationship between the SM use distance and the time passed to reach this. More precisely, SM relates the regular use of SM applications in the operations and transactions of the company to the number of years the firm has been operating since 2004 (2004 can be considered the year when SM tools started being used by companies (Michaelidou, Siamagka and Christodoulides 2011; O'Reilly and Musser 2007)). So, if a firm is using SM in one type of transactions while another firm is using SM for all its transactions, and both have been operating 12 years (the difference between 2015 and 2004) the speed of use of SM will be higher for the second one than for the first one. Likewise, a firm operating since 2008 could be faster in the use of SM than a firm operating since 2000 if the former is using SM tools in more transactions than the latter. Therefore, "speed of use of SM" reflects the intensification of the implementation of these media by the firm since the SM technology emergence in the world market.

The scale used to measure the "Speed of use of Social Media (SM)" was adapted from the scale used by Ifinedo (2011). More precisely, Speed of use of SM will be conceptualized in this research as a reflective construct formed by four observable variables relating operations and transactions where the firms use SM tools and the number of years the firm has been operating since the emergence of these media. To measure the general usage of SM this research used the four items proposed by Ifinedo (2011) that were anchored on a five-point Likert scale ranging from "strongly disagree" to "strongly agree" in which participants were asked to indicate an appropriate response. Then, to calculate the speed of use of SM, each item is divided by the number of years operating during the existence of these applications (since 2004).

We consider the construct "speed of use of SM" a reflective construct considering the decision rules for determining whether a construct is formative or reflective provided by Jarvis et al. (2003, table 1 p. 203): the direction of causality is from constructs to items, indicators are manifestations of the construct, changes in the indicators would not cause change in the construct but changes in the construct do cause change in the indicators. Furthermore, indicators are interchangeable, share a common theme and drop an indicator would not alter the conceptual domain of the construct. On the other hand, indicators covariance with each other and a change in one of the indicators is associated with changes in the other indicators. Finally, indicators have the same antecedents and consequences.

The operationalization of the constructs appears in Table 2 .

The moderator variables were assessed as follows: firm size was measured by number of employees and divided into two groups, SMEs as those with less than 250 workers, and large companies as those with more than 205 workers. Sector was divided as B2C (retail and services) and B2B companies (manufacturing and construction). The export intensity was assessed as high export intensity and low export intensity. Export intensity, calculated as export sales as percentage of total sales, allows capture different levels of internationalization by exporting firms in this research and it is not considered as a proxy of level of international commitment, as done in other studies. Therefore, the scores were divided at the fiftieth percentile of the total group, and companies were assigned to the high export intensity group if they have a value above the fiftieth percentile, and to the low export intensity group if they have a value under the fiftieth percentile.

\section{Data Analysis Technique}

A structural equation modelling (SEM), specifically partial least squares (PLS), is proposed to assess the measurement and structural model. This technique is used because is more appropriate for this research in view of the research objectives and exploratory nature of the study (the conceptualization of speed of internationalization and speed of use of social media) (Lew and Sinkovics 2013), studies with small sample sizes (Fornell and Bookstein 1982), the non-normal distribution of most indicators 
Table 2. Constructs and measures

\begin{tabular}{|c|c|c|c|c|}
\hline Construct & Indicators & Label & Measurement & Source \\
\hline \multirow{2}{*}{$\begin{array}{l}\text { Speed of learning } \\
\text { from repetition } \\
\text { of international } \\
\text { activities } \\
\text { (REPETITION) }\end{array}$} & $\begin{array}{l}\text { Speed of achieving } \\
\text { regular exports }\end{array}$ & REGEXP & $\begin{array}{l}\text { Number of years regularly exporting/number } \\
\text { of years operating }\end{array}$ & \multirow[t]{2}{*}{$\begin{array}{l}\text { Chetty et } \\
\text { al. (2014) }\end{array}$} \\
\hline & $\begin{array}{l}\text { Speed of obtaining the } \\
\text { first export order }\end{array}$ & FIRSTEXP & $\begin{array}{l}\text { Number of years since the first export order/ } \\
\text { number of years operating }\end{array}$ & \\
\hline \multirow[t]{2}{*}{$\begin{array}{l}\text { Speed of learning } \\
\text { from diversity } \\
\text { of international } \\
\text { activities } \\
\text { (DIVERSITY) }\end{array}$} & $\begin{array}{l}\text { Speed of geographic } \\
\text { scope of a firm's } \\
\text { international } \\
\text { operations }\end{array}$ & COUNTR & $\begin{array}{l}\text { Number of countries/number of years } \\
\text { operating }\end{array}$ & \multirow[t]{2}{*}{$\begin{array}{l}\text { Chetty et } \\
\text { al. (2014) }\end{array}$} \\
\hline & $\begin{array}{l}\text { Speed of diversity } \\
\text { of entry modes used } \\
\text { in international } \\
\text { operations }\end{array}$ & MOES & $\begin{array}{l}\text { Number of entry modes/number of years } \\
\text { operating }\end{array}$ & \\
\hline \multirow{2}{*}{$\begin{array}{l}\text { Speed of } \\
\text { international } \\
\text { learning } \\
\text { (LEARNING) }\end{array}$} & $\begin{array}{l}\text { Speed of learning } \\
\text { from repetition of } \\
\text { international activities }\end{array}$ & REPETITION & Latent variable scores & \multirow[t]{2}{*}{$\begin{array}{l}\text { Chetty et } \\
\text { al. (2014) }\end{array}$} \\
\hline & $\begin{array}{l}\text { Speed of learning } \\
\text { from diversity of } \\
\text { international activities }\end{array}$ & DIVERSITY & Latent variable scores & \\
\hline \multirow{3}{*}{$\begin{array}{l}\text { Speed of } \\
\text { committing } \\
\text { internationally } \\
(\text { COMMIT })\end{array}$} & $\begin{array}{l}\text { Speed of committing } \\
\text { staff in international } \\
\text { activities }\end{array}$ & PEOPLE & $\begin{array}{l}\text { Number of employees in international } \\
\text { activities/number of years operating }\end{array}$ & \multirow[t]{3}{*}{$\begin{array}{l}\text { Chetty et } \\
\text { al. (2014) }\end{array}$} \\
\hline & $\begin{array}{l}\text { Speed of using a firm's } \\
\text { foreign language skills }\end{array}$ & LANGUAGE & $\begin{array}{l}\text { Number of languages used/number of years } \\
\text { operating }\end{array}$ & \\
\hline & $\begin{array}{l}\text { Speed of entry modes } \\
\text { commitment }\end{array}$ & INVEST & $\begin{array}{l}\text { Entry mode with foreign investment (yes/ } \\
\text { no)/number of years operating }\end{array}$ & \\
\hline \multirow{2}{*}{$\begin{array}{l}\text { Speed of } \\
\text { internationalization } \\
\text { (Speed Int.) }\end{array}$} & $\begin{array}{l}\text { Speed of international } \\
\text { learning }\end{array}$ & LEARNING & Latent variable scores & \multirow[t]{2}{*}{$\begin{array}{l}\text { Chetty et } \\
\text { al. (2014) }\end{array}$} \\
\hline & $\begin{array}{l}\text { Speed of committing } \\
\text { internationally }\end{array}$ & COMMIT & Latent variable scores & \\
\hline \multirow[t]{4}{*}{$\begin{array}{l}\text { Speed of use of } \\
\text { Social Media }\end{array}$} & \multirow[t]{4}{*}{$\begin{array}{l}\text { Speed of using social } \\
\text { media in regular } \\
\text { activities }\end{array}$} & USE1 & $\begin{array}{l}\text { "Our company makes use of Social Media } \\
\text { very often"/number of years operating } \\
\text { during the existence of Social Media } \\
\end{array}$ & \multirow{4}{*}{$\begin{array}{l}\text { Items } \\
\text { adapted } \\
\text { from } \\
\text { Ifinedo } \\
(2011)\end{array}$} \\
\hline & & USE2 & $\begin{array}{l}\text { "Our company uses Social Media, at all } \\
\text { times, for its transactions"/number of years } \\
\text { operating during the existence of Social } \\
\text { Media }\end{array}$ & \\
\hline & & USE3 & $\begin{array}{l}\text { "Our company uses Social Media its critical } \\
\text { operations"/ number of years operating } \\
\text { during the existence of Social Media }\end{array}$ & \\
\hline & & USE4 & $\begin{array}{l}\text { "The number of business operations and } \\
\text { activities in my company that requires } \\
\text { Social Media" /number of years operating } \\
\text { during the existence of Social Media }\end{array}$ & \\
\hline
\end{tabular}

(Chin et al. 2003) and, what is most important, the presence of second and third-order formative constructs in the measurement model (Hair et al. 2012).

We followed one of the PLS-based methods for estimating models with higher-order constructs, as Chetty et al. (2014) used to conceptualized speed of internationalization, the "two-stage" approach (e.g., Henseler, Wilson, Götz and Hautvast 2007; Wetzels, Oderkerken-Schröder and van Oppen 2009), and used latent variable scores in the estimation of the second and third-order constructs.

SmartPLS 2.0 software was used to analyse the data (Ringle et al. 2005). The stability of the estimates was tested via a bootstrap re-sampling procedure (500 sub-samples (Chin 1998)). 


\section{RESULTS}

A PLS model is analysed in two stages: first, the assessment of the reliability and validity of the measurement model, and second, the assessment of the structural model.

\section{Reliability and Validity Assessment}

Firstly, following the approach of other studies (e.g. Ifinedo 2011; Alegre and Chiva 2013), procedural remedies for controlling common method biases were followed (Podsakoff et al. 2003): clear and concise questions were used in the questionnaire, respondents' anonymity was assured and the Harmon one-factor test was used to assess if such biases were a problem in the sample. Results show that common method bias was not a relevant concern in the data set: the factor analysis conducted in the overall sample resulted in two factors with eigenvalues greater than 1 (accounting for $67.3 \%$ of the total variance).

Secondly, an analysis of the validity and reliability of the scales employed in the model was performed. As one of the objectives is to analyse the moderator effect of size, sector and export intensity in the relationship proposed, this research also tested the reliability and validity for these subgroups, to asses that the measurement instrument is reliable. Therefore, we separated the companies into two groups for each moderator: SMEs -those with less than 250 employees- and large companies for size, B2C and B2B companies for sector, and companies with a high export intensity and companies with a low export intensity. Therefore, we will analyse the validity and reliability of the scales for the 7 models (Total, SMEs, big companies, B2C, B2B, high and low export intensity).

The scales' development was founded on the review of the most relevant literature, thus assuring the content validity of the measurements instruments (Cronbach,1971) (Table 2).

To analyse the reliability of the constructs, we first conducted an exploratory factor analysis (EFA) with SPSS software. The consideration of multiple items for each construct increases construct reliability (Terblanche and Boshoff 2008). Using EFA, and considering the different items for each construct, we found that only one dimension appeared for all constructs. Therefore, EFA confirmed the unidimensionality of the constructs considered in the model. The item-total correlation, which measures the correlation of each item with the sum of the remaining items that constitute the scale, is above the minimum of 0.3 recommended by Nurosis (1993) for all constructs in the sample used.

The results of the PLS for reflective indicators are reported in Table 3. Convergent validity is verified by analysing the factor loadings and their significance. We deleted one item (PEOPLE) of the "Speed of committing internationally" construct since the item loading estimates lower than 0.4 (Bagozzi and Yi 1988). The results of the final re-specified measurement model provide a good convergent validity. The individual item loadings in our models are higher than 0.6 (Bagozzi and Yi 1988), and the average of the item-to-factor loadings are higher than 0.7 (Hair et al. 2006). Also, we checked the significance of the loadings with a re-sampling procedure (500 sub-samples) for obtaining $\mathrm{t}$-statistic values. They were all significant $(\mathrm{p}<.001)$. These findings provide evidence supporting the convergent validity of all the reflective constructs for the seven models. Composite reliability (CR) represents the shared variance among a set of observed variables measuring an underlying construct (Fornell and Larcker 1981). Generally, a CR of at least 0.60 is considered desirable (Bagozzi and Yi 1988). This requirement is fulfilled for every factor in the seven models. The average variance extracted (AVE) was also calculated for each construct; the resulting AVE values were greater than 0.50 (Fornell and Larcker 1981). Therefore, the four constructs for each model demonstrated acceptable levels of reliability.

The weights for the two dimensions forming speed of internationalization are significant (see Table 4) for each model, with values higher for speed of committing internationally than for speed of international learning. This means that the former makes a higher contribution to speed of internationalization than the latter. In addition, the speed of learning from diversity of activities makes a more important and significant contribution to speed of international learning than learning from 
repetition of activities, as Chetty et al. (2004) included in their study. As a standard precaution when working with formative measures (Mathieson, Peacock and Chin 2001), we tested for multicollinearity by calculating the variance inflation factor (VIF) and the tolerance values. A rule of thumb from econometrics states that VIFs greater than 10 reveal a critical level of multicollinearity. If the VIF is equal to 1 there is no multicollinearity among factors. In our case, the VIF is around 1, which indicates some correlation, but not enough to be overly concerned about (Henseler et al. 2009).

Finally, the comparison of bivariate correlations and square roots of the AVEs, presented in Table 5, show an adequate discriminant validity of all constructs for every model, since all diagonal values exceeded the inter-construct correlations. Discriminant validity indicates the extent to which a given construct is different from other latent variables.

On the basis of all criteria, we can accept this measure as a valuable instrument built from reliable and valid constructs for the seven models.

\section{Structural Model}

First, as in the validity assessment, the model was run separately for each subgroup to test the moderator effect and the relationship for each group (bootstrapping of 500 sub-samples was implemented). To assess the predictive ability of the structural model this research followed the approach proposed by Falk and Miller (1992) that the R2 value (variance accounted for) of each of the dependent constructs exceeds the 0.1 value. Table 6 shows that the R2 values in the dependent variables are higher than the critical level mentioned for each model.

Another test applied was the Stone-Geisser test of predictive relevance (Q2). This test can be used as an additional assessment of model fit in PLS analysis (Geisser 1975). The Blindfolding technique was used to calculate de Q2. Models with Q2 greater than zero are considered to have predictive relevance (Chin, 1988). In this case Q2 is positive for all predicted variables.

Second, the multigroup path coefficient differences were examined based on the procedure suggested by Keil et al. (2000) and Chin (2000). These authors suggest to apply an unpaired samples t-test to the group-specific model parameters using the standard deviations of the estimates resulting from bootstrapping. The parametric test uses the path coefficients and the standard errors of the structural paths calculated by PLS with the samples of the two groups, using the following expression of t-value for multigroup comparison test (1) (see Chin 2000) ( $\mathrm{m}=$ group 1 sample size and $\mathrm{n}=$ group 2 sample size):

$$
t=\frac{\beta_{\text {group } 1}-\beta_{\text {group } 2}}{\sqrt{\frac{m-1}{m+n-2} \times S E_{\text {group } 1}^{2}+\frac{n-1}{m+n-2} \times S E_{\text {group } 2}^{2}} \times \sqrt{\frac{1}{m}+\frac{1}{n}}}
$$

This statistic follows a t-distribution with $\mathrm{m}+\mathrm{n}-2$ degrees of freedom. The subsample-specific path coefficients are denoted as $\beta$, the sizes of the subsamples as $m$ and $n$, and the patch coefficient standard errors as resulting from bootstrapping as SE.

Table 6 and Figure 2 show a synthesis of the results obtained for the causal and moderated hypothesis testing. Consistent with Chin (1988), bootstrapping (500 re-samples) was used to generate t-values. Support for each general hypothesis can be determined by examining the sign and statistical significance of the t-values. In the overall model, the results obtained allow state that the speed of use of social media influences in the speed of the internationalization ${ }^{1}$.

In addition, the impact of moderating variables on the proposed relationship was significant for the sector and for the export intensity, since t-value for multi-group comparison are significant at a level of 0.01 . However, firm size does not have a moderator effect. In other words, whether the firms is $\mathrm{B} 2 \mathrm{C}$ or $\mathrm{B} 2 \mathrm{~B}$ or whether the firm have high export intensity or low export intensity have impact on the proposed hypothesis, being stronger this relationship in $\mathrm{B} 2 \mathrm{C}$ companies and companies of higher export intensity. 
Table 3. Internal consistency and convergent validity for constructs with reflective indicators

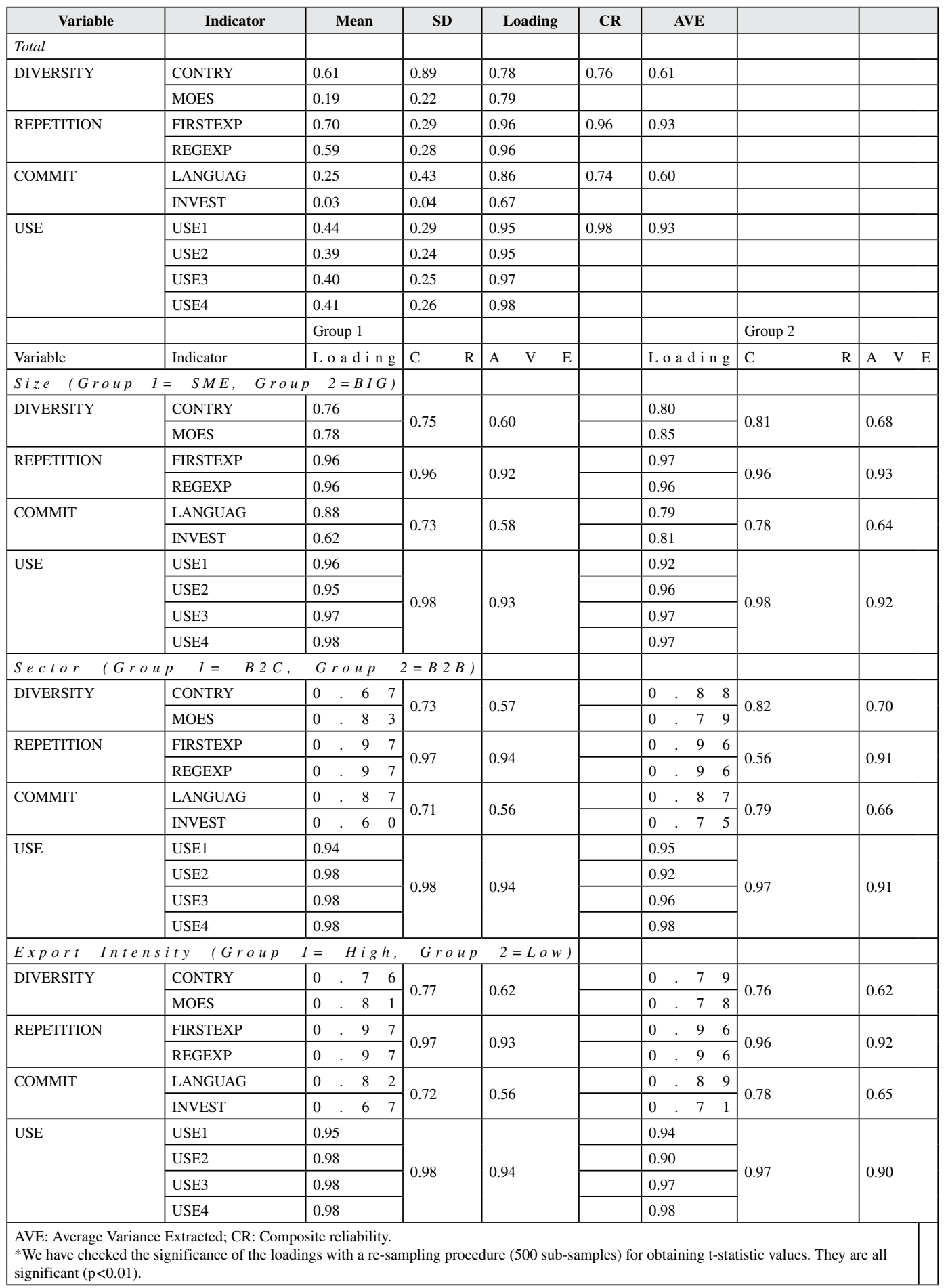


Table 4. Item weights and multicollinearity tests for constructs with formative indicators

\begin{tabular}{|c|c|c|c|c|c|c|c|c|}
\hline \multirow[b]{2}{*}{$\begin{array}{l}\text { Construct// } \\
\text { indicator }\end{array}$} & \multicolumn{4}{|c|}{ Group 1} & \multicolumn{4}{|c|}{ Group 2} \\
\hline & Weight & $\begin{array}{c}t \text {-value } \\
\text { (bootstrap) }\end{array}$ & Tolerance & VIF & Weight & $\begin{array}{c}t \text {-value } \\
\text { (bootstrap) }\end{array}$ & Tolerance & VIF \\
\hline \multicolumn{9}{|l|}{ Total } \\
\hline \multicolumn{9}{|l|}{ LEARNING } \\
\hline REPETITION & $0.603 * * *$ & 10.995 & 0.911 & 1.098 & & & & \\
\hline DIVERSITY & $0.638 * * *$ & 13.400 & 0.911 & 1.098 & & & & \\
\hline \multicolumn{9}{|l|}{ Speed Int. } \\
\hline LEARNING & $0.285^{* *}$ & 2.432 & 0.820 & 1.220 & & & & \\
\hline COMMIT & $0.845^{* * *}$ & 10.373 & 0.820 & 1.220 & & & & \\
\hline \multicolumn{9}{|c|}{ Size $($ Group $1=$ SME, Group 2=BIG) } \\
\hline \multicolumn{9}{|l|}{ LEARNING } \\
\hline REPETITION & $0.609 * * *$ & 9.960 & 0.908 & 1.101 & $0.550 * * *$ & 6.477 & 0.895 & 1.118 \\
\hline DIVERSITY & $0.630 * * *$ & 11.197 & 0.908 & 1.101 & $0.676^{* * *}$ & 9.798 & 0.895 & 1.118 \\
\hline \multicolumn{9}{|l|}{ Speed Int. } \\
\hline LEARNING & $0.200 * *$ & 2.544 & 0.784 & 1.276 & $0.507 *$ & 2.031 & 0.860 & 1.163 \\
\hline COMMIT & $0.891 * * *$ & 18.261 & 0.784 & 1.276 & $0.693 * * *$ & 2.748 & 0.860 & 1.163 \\
\hline \multicolumn{9}{|c|}{ Sector $($ Group $1=B 2 C$, Group $2=B 2 B)$} \\
\hline \multicolumn{9}{|l|}{ LEARNING } \\
\hline REPETITION & $0.574 * * *$ & 10.585 & 0.888 & 1.126 & $0.591 * * *$ & 9.805 & 0.89 & 1.125 \\
\hline DIVERSITY & $0.649 * * *$ & 13.870 & 0.888 & 1.126 & $0.633 * * *$ & 10.400 & 0.89 & 1.125 \\
\hline \multicolumn{9}{|l|}{ Speed Int. } \\
\hline LEARNING & $0.226^{*}$ & 2.297 & 0.754 & 1.327 & $0.478^{*}$ & 2.351 & 0.855 & 1.169 \\
\hline COMMIT & $0.868 * * *$ & 13.036 & 0.754 & 1.327 & $0.715^{* * *}$ & 4.050 & 0.855 & 1.169 \\
\hline \multicolumn{9}{|c|}{ Export Intensity $($ Group 1= High, Group 2=Low) } \\
\hline \multicolumn{9}{|l|}{ LEARNING } \\
\hline REPETITION & $0.575^{* * *}$ & 7.967 & 0.921 & 1.085 & $0.653 * * *$ & 9.385 & 0.890 & 1.123 \\
\hline DIVERSITY & $0.672 * * *$ & 11.104 & 0.921 & 1.085 & $0.572 * * *$ & 8.151 & 0.890 & 1.123 \\
\hline \multicolumn{9}{|l|}{ Speed Int. } \\
\hline LEARNING & $0.220 *$ & 2.366 & 0.788 & 1.269 & $0.427 *$ & 2.045 & 0.861 & 1.161 \\
\hline COMMIT & $0.879 * * *$ & 14.838 & 0.788 & 1.269 & $0.759 * * *$ & 4.371 & 0.861 & 1.161 \\
\hline
\end{tabular}

\section{CONCLUSION}

The speed of use of SM by firms influences positively in the speed of their internationalization processes: the more rapidly SM tools are integrated in the activities of the company, the higher the speed of internationalization.

From an academic point of view, and drawing on the resource- and knowledge based views of the firm, with this result we contribute to the literature that identifies intangible resources to explain 
Table 5. Discriminant validity: first order latent variables correlations and square root of the average variances extracted

\begin{tabular}{|c|c|c|c|c|c|c|c|c|}
\hline \multirow[b]{2}{*}{ Variable } & \multicolumn{4}{|c|}{ Group 1} & \multicolumn{4}{|c|}{ Group 2} \\
\hline & DIVERSITY & REPETITION & COMMIT & USE & DIVERSITY & REPETITION & COMMIT & USE \\
\hline \multicolumn{9}{|l|}{ Total } \\
\hline DIVERSITY & 0.78 & & & & & & & \\
\hline REPETITION & 0.30 & 0.96 & & & & & & \\
\hline COMMIT & 0.57 & 0.27 & 0.77 & & & & & \\
\hline USE & 0.56 & 0.22 & 0.57 & 0.96 & & & & \\
\hline \multicolumn{9}{|c|}{ Size (Group $1=$ SME, Group $2=B I G)$} \\
\hline DIVERSITY & 0.77 & & & & 0.83 & & & \\
\hline REPETITION & 0.30 & 0.96 & & & 0.32 & 0.97 & & \\
\hline COMMIT & 0.61 & 0.30 & 0.76 & & 0.52 & 0.22 & 0.80 & \\
\hline USE & 0.62 & 0.25 & 0.67 & 0.96 & 0.42 & 0.19 & 0.32 & 0.96 \\
\hline \multicolumn{9}{|c|}{ Sector $($ Group $1=B 2 C$, Group $2=B 2 B)$} \\
\hline DIVERSITY & 0.76 & & & & 0.84 & & & \\
\hline REPETITION & 0.33 & 0.97 & & & 0.33 & 0.96 & & \\
\hline COMMIT & 0.72 & 0.32 & 0.75 & & 0.44 & 0.24 & 0.81 & \\
\hline USE & 0.68 & 0.33 & 0.74 & 0.97 & 0.41 & 0.14 & 0.34 & 0.95 \\
\hline \multicolumn{9}{|c|}{ Export Intensity (Group 1= High, Group 2=Low) } \\
\hline DIVERSITY & 0.79 & & & & 0.78 & & & \\
\hline REPETITION & 0.28 & 0.97 & & & 0.33 & 0.96 & & \\
\hline COMMIT & 0.65 & 0.28 & 0.75 & & 0.45 & 0.27 & 0.80 & \\
\hline USE & 0.67 & 0.26 & 0.70 & 0.97 & 0.38 & 0.17 & 0.36 & 0.95 \\
\hline
\end{tabular}

speed of internationalization. As we mention in the introduction, the faster a company uses social networks sites, the faster the company can obtain a common language with their international ties that, at the same time, allow the company to develop a faster internationalization process (Musteen et al. 2010). Furthermore, firms can establish online brand communities based on a structured set of social relations among admirers of a brand, these communities form brand trustworthiness that induces a high degree of brand loyalty and those individuals with higher brand loyalty are likely to purchase the brand's products more frequently as well as in a higher volume (Kananukul et al. 2015).

In addition, our results prove that sector and export intensity moderate the proposed relationship, while the firm size does not have a moderator effect. In other words, whether the firms are B2C or B2B or whether the firm has high export intensity or low export intensity have impact on the relationship between the speed of use of SM and the speed of internationalization: the effect is stronger in B2C companies and in higher export intensity companies.

In relation to the stronger effect in B2C companies, as Jussila, Kärkkäinen and Aramo-Immonen (2014) recognize, there are significant differences between the B2B and B2C companies in the markets, products and product development. For instance, products produced by B2C organizations are less complex and the development of new products takes significantly less time than products produced by B2B organizations, whose customers are less in number but are large organizations instead of single persons. 
Table 6. Hypotheses and moderating effect testing

\begin{tabular}{|c|c|c|c|c|c|c|c|c|}
\hline \multirow{3}{*}{ Path } & \multirow{2}{*}{\multicolumn{2}{|c|}{ Global }} & & & \multicolumn{4}{|c|}{ Multigroup analysis } \\
\hline & & & \multicolumn{2}{|c|}{ Group 1} & \multicolumn{2}{|c|}{ Group 2} & \multirow[b]{2}{*}{$\mathbf{t}[\mathbf{m g p}]$} & \multirow[b]{2}{*}{$p$} \\
\hline & $\begin{array}{c}\text { Stand } \\
\text { coefficients }\end{array}$ & $\begin{array}{c}\text { t-value } \\
\text { (bootstrap) }\end{array}$ & $\begin{array}{c}\text { Stand } \\
\text { coefficients }\end{array}$ & $\begin{array}{c}\text { t-value } \\
\text { (bootstrap) }\end{array}$ & $\begin{array}{c}\text { Stand } \\
\text { coefficients }\end{array}$ & $\begin{array}{c}\text { t-value } \\
\text { (bootstrap) }\end{array}$ & & \\
\hline $\begin{array}{l}\text { Total } \\
\text { Speed of use of } \\
\text { SM } \rightarrow \text { Speed Int. }\end{array}$ & $0.977 * * *$ & 194.076 & & & & & & \\
\hline $\mathrm{R}^{2}$ (Speed Int.) & $\begin{array}{lllll}0 & . & 9 & 5 & 4\end{array}$ & & & & & & & \\
\hline $\mathrm{Q}^{2}$ (Speed Int.) & $\begin{array}{llll}0.9 & 3 & 6\end{array}$ & & & & & & & \\
\hline \multicolumn{3}{|c|}{ Size (Group 1= SME, Group 2=BIG) } & & & & & & \\
\hline $\begin{array}{l}\text { Speed of use of } \\
\text { SM } \rightarrow \text { Speed Int. }\end{array}$ & & & $0.979 * * *$ & 252.749 & $0.979 * * *$ & 140.884 & -0.174 & $0.8620^{\text {n.s. }}$ \\
\hline $\mathrm{R}^{2}$ (Speed Int.) & & & $\begin{array}{llll}0 & 9 & 5 & 8 \\
\end{array}$ & & $\begin{array}{lllll}0 & 9 & 5 & 9\end{array}$ & & & \\
\hline $\mathrm{Q}^{2}$ (Speed Int.) & & & 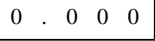 & & $\begin{array}{lllll}0 & 9 & 1 & 0 \\
\end{array}$ & & & \\
\hline \multicolumn{3}{|c|}{ Sector $($ Group $1=B 2 C$, Group $2=B 2 B)$} & & & & & & \\
\hline $\begin{array}{l}\text { Speed of use of } \\
\text { SM } \rightarrow \text { Speed Int. }\end{array}$ & & & $0.982 * * *$ & 197.256 & $0.978 * * *$ & 117.074 & 2.881 & $0.004 * * *$ \\
\hline $\mathrm{R}^{2}$ (Speed Int.) & & & $\begin{array}{llll}0 & 9 & 6 & 5 \\
\end{array}$ & & $\begin{array}{llll}0 & 9 & 5 & 6\end{array}$ & & & \\
\hline $\mathrm{Q}^{2}$ (Speed Int.) & & & $\begin{array}{llll}0 & 9 & 1 & 4 \\
\end{array}$ & & $\begin{array}{lllll}0 & 9 & 9 & 3 & 5 \\
\end{array}$ & & & \\
\hline \multicolumn{4}{|c|}{ Export Intensity (Group 1= High, Group 2=Low) } & & & & & \\
\hline $\begin{array}{l}\text { Speed of use of } \\
\text { SM } \rightarrow \text { Speed Int. }\end{array}$ & & & $0.981 * * *$ & 240.863 & $0.976 * * *$ & 122.387 & 3.822 & $0.000 * * *$ \\
\hline $\mathrm{R}^{2}$ (Speed Int.) & & & $\begin{array}{llll}0 & 9 & 6 & 3 \\
\end{array}$ & & 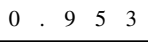 & & & \\
\hline $\mathrm{Q}^{2}$ (Speed Int.) & & & 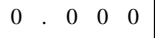 & & $\begin{array}{llll}0 & 9 & 9 & 2\end{array}$ & & & \\
\hline
\end{tabular}

Figure 2. Hypotheses testing

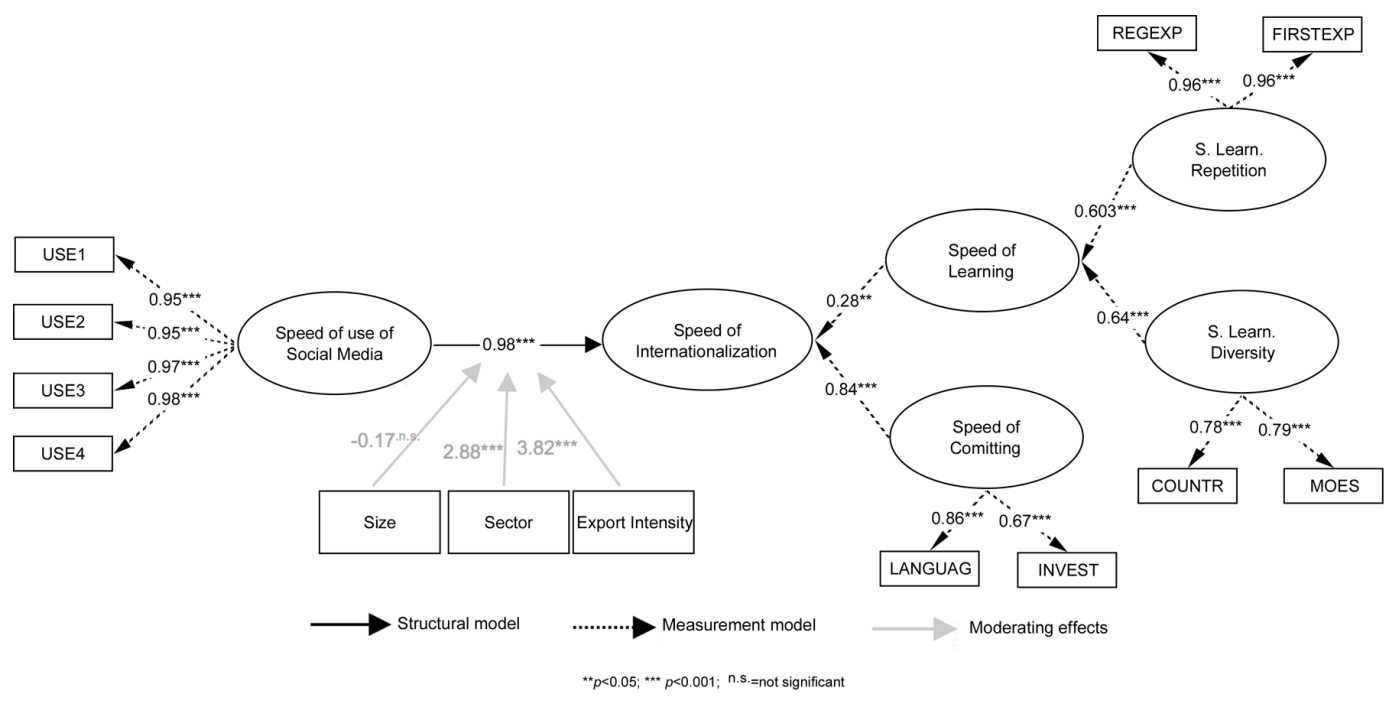


For B2B organizations the co-operation with customers is generally more direct and more intense than in the B2C organizations due to the number of buyers. This is precisely one of the aspects that the implementation and adoption of SM can change for B2C organizations: SM facilitates an intense and direct cooperation with customers, domestic and foreign, what accelerates and increases customer engagement, faithfulness, brand awareness, loyalty, and domestic and foreign sales (e.g., Kumar and Mirchandani 2012; Wiersema 2013).

This intense and direct cooperation with customers that SM permit is also behind the stronger effect of the speed of use of SM on the speed of internationalization in higher export intensity companies. For these companies, international markets constitute the main destiny of their products; and the possibility of contacting directly with their foreign consumers, obtain direct information as well as suggestions related to current and potential products through SM, accelerate the internationalization process.

Finally regarding possible moderators in the relationship between speed of use of SM and speed of internationalization, the results show that size does not have a moderator effect. In other words, the effect of the speed of use of SM on the speed of internationalization does not differ for smaller and medium size companies than for larger firms. Many scholars had thought that firm size is a good proxy of the stock of resources available to enhance the presence of the firm in foreign markets (Prasad et al. 2001), however the effect on the speed of internationalization of integrating SM in the regular activities of the company is not related to the stock of resources of the company. So, small and medium size companies are not in disadvantage regarding larger ones when the research focuses on the integration and exploitation of SM to accelerate the internationalization process. This contradicts to earlier studies of technology adoption suggesting that firm size correlates positively with the use of technology (e.g., Del Aguila-Obra and Padilla-Melendez 2006) and, as Jussila et al. (2014, p. 612) suggest: "possible explanations for this include the relatively limited financial resources needed for the adoption (see e.g., Michaelidou et al. 2011), and the ease of adoption and the cost effectiveness of at least some SM approaches, such as social networking sites or one-way communication related approaches used e.g., in marketing of smaller companies."

From our perspective, the effect of size on the internationalization process and results has obtained mixed evidences in the literature, for some authors smaller firms are in disadvantage (Nazar and Saleem 2009), while for others smaller firms are also seen quicker and more flexible than the larger ones due to structural simplicity, and therefore efficient adaptation can provide them a competitive advantage in responding to the specific requirements of foreign buyers (Verwaal and Donkers 2002). From our perspective, the result of the current research regarding the no moderation effect of size in the relationship between speed of use of SM and speed of internationalization reinforces previous works where size has not been found as a significant explanatory variable of exports (Moen 1999; Pla-Barber and Alegre 2007).

From a managerial point of view, our results reinforce Durkin, McGowan and McKeown (2013, p.720) statement that: "practitioners increasingly recognize that a business opportunity exists in effective SM adoption, to build and maintain issues of trust and commitment with key stakeholders in their network, such as customers, and to enhance and maintain quality in those networked relationships (Harris and Rae 2010)". In fact, our research allows us to transmit to practitioners that:

1. The speed of use of SM allows to firms to build and maintain trust and commitment with key stakeholders in their network, and to enhance and maintain quality in those networked relationships (Harris and Rae 2010).

2. Furthermore, and being focused in the international domain, as Mathews et al. (2012) point out, with a faster use of social media companies will have a greater ability to take advantage of international markets opportunities. Speed of internationalization is related to commitment and knowledge of international markets (Chetty et al. 2014) and the use of SM increase the commitment with customers and the knowledge acquisition of foreign markets. In fact, drawing 
on the literature on relationship marketing, the importance of commitment has been widely recognized in predicting continued use of organizational IT applications in general and webbased online services in particular (Kim and Son 2009). Likewise, the potential of SM to replicate dimensions of face-to-face interaction in a virtual environment and to accommodate high levels of self-disclosure, as suggested by Kaplan and Haenlein (2010), has the potential to significantly complement personal contact networking activity, a key marketing resource of owner/managers. So, in line with Gamboa and Gonçalves (2014, p. 711), "the more highly networked the organization, the more benefits that can be derived from using Web 2.0 tools".

3. A faster SM adoption allows the reduction in the costs of communicating with foreign customers/ suppliers and of gathering information about foreign competitors. The support of distinctive competencies and skills in other business functions can be reasons explaining why the use of SM by companies oriented towards international markets accelerate their internationalization speed (Pezderka et al. 2012; Zhang et al. 2013).

4. Furthermore, as some authors have identified (Durkin et al.2013; Gamboa and Gonçalves 2014; Calefato, Lanubile and Novielli 2015), the speed of use of social media allows companies to improve customer satisfaction and strengthen client (and other stakeholders) relations, both drivers of loyalty, via dynamic interaction with their fans on SM: "via SM, companies now have at their disposal tools that allow them to communicate with millions of customers simultaneously. This ability allows information to be delivered quickly through feedback and has lasting impact through the establishment of long-term relationships" (Gamboa and Gonçalves 2014, p. 711).

Therefore, our findings demonstrate the effect of quickly adopting SM in the internationalization process of the company: firms increasing the speed of use of SM in their activities will increase their speed of internationalization. Therefore, managers of companies, no matter size, with an interest in foreign markets should allocate more resources to SM integration and should try to take advantage of the SM sites that their target buyers tend to frequent. Considering the adoption literature, LinkedIn, Twitter, or Facebook are a natural choice because of their relative ease of trial and use, perceived advantages, and compatibility to current user needs and systems, which are major factors in organizational adoption of innovations (Jussila et al. 2014). This suggested adoption and integration is especially true for $\mathrm{B} 2 \mathrm{C}$ companies and companies that highly rely in foreign markets to survive. Considering the importance of relationship building in foreign markets, SM offer a viable tool for internationalized companies to foster and speed customer-brand relationships up.

Although this study contributes to current literature by exploring and improving the understanding of the integration of SM in the activities of export-oriented companies, it is not free of some limitations that invite continued research. Firstly, the sample allows generalize the results to internationalized firms that have used exports to reach foreign markets. More detailed research should be performed considering other entry modes or ways of becoming an internationalized firm.

Another data limitation is related to its cross-section collection. Although the research has tried to collect information from a dynamic perspective, due to the fact it considers a longitudinal concept as "speed", future research should benefit of working with panel data.

This study also opens several areas for further research because it has identified a positive influence of the speed of implementation of SM in firms with an international orientation, increasing the speed of its internationalization process (because SM increase the direct and constant connection and interchange of information with foreign stakeholders of the company). Some studies have already discussed the potential and the role of Web 2.0 and social networking in future knowledge management systems of companies, for example Hustad and Teigland (2008) focused on multinational firms. The results of their study point out that when incorporated in an organization's routines, SM may enable companies to more fully leverage the knowledge sharing and creation potential of its employees across distributed locations than traditional knowledge management has done in the past. However, since few studies have focused on the role of SM in knowledge management, future research should pay attention 
to how internationalized companies proceed in their efforts of implementing these media (possible barriers companies could face to implement and use these tools in different operations) and how this may influence their existing knowledge management strategy, practices and organizational aspects.

\section{ACKNOWLEDGMENT}

This research was supported by the the Spanish Ministry of Economics and Competitiveness (ECO2013-44027-P). 


\section{REFERENCES}

Acedo, F. J., \& Jones, M. V. (2007). Speed of internationalization and entrepreneurial cognition: Insights and a comparison between international new ventures, exporters and domestic firms. Journal of World Business, 42(3), 236-252. doi:10.1016/j.jwb.2007.04.012

Agnihotri, R., Kothandaraman, P., Kashyap, R., \& Singh, R. (2012). Bringing” Social” into Sales: The Impact of Salespeople's Social Media Use on Service Behaviors and Value Creation. Journal of Personal Selling \& Sales Management, 3(3), 333-348. doi:10.2753/PSS0885-3134320304

Alegre, J., \& Chiva, R. (2013). Linking Entrepreneurial Orientation and Firm Performance: The Role of Organizational Learning Capability and Innovation Performance. Journal of Small Business Management, 51(4), 491-507. doi:10.1111/jsbm.12005

Bagozzi, R. P., \& Yi, Y. (1988). On the evaluation of structural equations models. Journal of the Academy of Marketing Science, 16(1), 74-94. doi:10.1007/BF02723327

Bonaccorsi, A. (1992). On the Relationship between Firm Size and Export Intensity. Journal of International Business Studies, 23(4), 605-635. doi:10.1057/palgrave.jibs.8490280

Brouthers, L. E., \& Nakos, G. (2005). The Role of Systematic International Market Selection on Small Firms' Export Performance. Journal of Small Business Management, 43(4), 363-381. doi:10.1111/j.1540627X.2005.00142.x

Calof, J. L. (1994). The Relationship Between Firm Size and Export Behaviour Revisited. Journal of International Business Studies, 25(2), 367-387. doi:10.1057/palgrave.jibs.8490205

Casillas, J. C., \& Moreno-Menéndez, A. M. (2014). Speed of the internationalization process: The role of diversity and depth in experiential learning. Journal of International Business Studies, 45(1), 85-101. doi:10.1057/ jibs.2013.29

Casillas, S., \& Acedo, F. J. (2013). Speed in the Internationalization Process of the Firm. International Journal of Management Reviews, 15(1), 15-29. doi:10.1111/j.1468-2370.2012.00331.x

Cavusgil, S. T., \& Zou, S. (1994). Marketing strategy-performance relationship: An investigation of the empirical link in export market ventures. Journal of Marketing, 58(1), 1-21. doi:10.1177/002224299405800101

Chetty, S., Johanson, M., \& Martín, O. M. (2014). Speed of internationalization: Conceptualization, measurement and validation. Journal of World Business, 49(4), 633-650. doi:10.1016/j.jwb.2013.12.014

Chin, W. W. (1988). The partial least squares approach to structural equation modeling. In G. A. Marcoulides (Ed.), Modern Methods for Business Research. Lawrence Erlbaum.

Chin, W. W. (2000). Frequently Asked Questions_Partial Least Squares and PLS-Graph. Available online at http://disc-nt.cba.uh.edu/chin/plsfaq/plsfaq.htm

Chin, W. W., Marcolin, B. L., \& Newsted, P. R. (2003). A partial least squares latent variable modeling approach for measuring interaction effects: Results from a Monte Carlo simulation study and an electronic-mail emotion/ adoption study. Information Systems Research, 14(2), 189-17. doi:10.1287/isre.14.2.189.16018

Constantinides, E., \& Fountain, S. (2008). Web 2.0: Conceptual foundations and Marketing Issues. Journal of Direct. Data and Digital Marketing Practice, 9(3), 231-244. doi:10.1057/palgrave.dddmp.4350098

Contractor, F. J., Hsu, C. C., \& Kundu, S. K. (2005). Explaining export performance: A comparative study of International New Ventures in Indian and Taiwanese Software Industry. Management International Review, $45(3), 83-110$.

Cronbach, L. J. (1971). Test validation. In R. L. Thorndike (Ed.), Educational Measurement. Washington, DC: American Council of Education.

Da Rocha, A., Cotta del Mello, R., Pacheco, H., \& de Abreu Farias, I. (2012). The international commitment of late-internationalizing Brazilian entrepreneurial firms. International Marketing Review, 29(3), 228-252. doi:10.1108/02651331211229741 
Del Aguila-Obra, A. R., \& Padilla-Melendez, A. (2006). Organizational factors affecting Internet technology adoption. Internet Research, 16(1), 9-110. doi:10.1108/10662240610642569

Durkin, M., McGowan, P., \& McKeown, N. (2013). Exploring social media adoption in small to medium-sized enteprirses in Ireland. Journal of Small Business and Enterprise Development, 20(4), 716-734. doi:10.1108/ JSBED-08-2012-0094

Falk, R. F., \& Miller, N. B. (1992). A Primer for Soft Modeling. Akron, OH: University of Akron Press.

Fornell, C., \& Bookstein, F. L. (1982). Two structural equation models: LISREL and PLS applied to customer exit-voice theory. JMR, Journal of Marketing Research, 19(4), 440-452. doi:10.1177/002224378201900406

Fornell, C., \& Larcker, D. F. (1981). Evaluating structural equations models with unobservable variables and measurement error. JMR, Journal of Marketing Research, 18(1), 39-50. doi:10.1177/002224378101800104

Gamboa, A. M., \& Gonçalves, H. M. (2014). Customer loyalty through social networks: Lessons from Zara on Facebook. Business Horizons, 57(6), 709-717. doi:10.1016/j.bushor.2014.07.003

García-García, R., García-Canal, E., \& Guillén, M. F. (2017). Rapid internationalization and long-term performance: The knowledge link. Journal of World Business, 52(1), 97-110. doi:10.1016/j.jwb.2016.09.005

Geisser, S. (1975). The predictive sample reuse method with applications. Journal of the American Statistical Association, 70(350), 320-328. doi:10.1080/01621459.1975.10479865

Giamanco, B., \& Gregoire, K. (2012). Tweet me, friend me, make me buy. Harvard Business Review, (JulyAugust): 88-93.

Goode, S. \& Stevens, K. (2000). An analysis of the business characteristics of adopters and non-adopters of World Wide Web Technology. Information Technology and Management, (1:1-2), 129-154.

Grandinetti, R., \& Mason, M. C. (2012). Internationalization modes other than exporting. European Business Review, 24(3), 236-254. doi:10.1108/09555341211222495

Hair, J. F., Black, W. C., Babin, B. J., Anderson, R. E., \& Tatham, R. L. (2006). Multivariate data analysis. Upper Saddle River, NJ: Prentice-Hall.

Hair, J. F., Sarstedt, M., Pieper, T. M., \& Ringle, C. M. (2012). The use of partial least squares structural equation modeling in strategic management research: A review of past practices and recommendations for future applications. Long Range Planning, 45(5), 320-340. doi:10.1016/j.lrp.2012.09.008

Harris, L., \& Rae, A. (2010). The online connection: Transforming marketing strategy for small businesses. The Journal of Business Strategy, 31(2), 4-12. doi:10.1108/02756661011025017

Henseler, J., Ringle, C. M., \& Sinkovics, R. R. (2009). The use of partial least squares path modeling in international marketing. In New Challenges to International Marketing. Emerald Group Publishing Limited.

Henseler, J., Wilson, B., Götz, O., \& Hautvast, C. (2007). Investigating the moderating role of fit on sports sponsoring and brand equity: A structural model. International Journal of Sports Marketing \& Sponsorship, 8(4), 321-329. doi:10.1108/IJSMS-08-04-2007-B005

Hilmersson, M., \& Johanson, M. (2016). Speed of SME internationalization and performance. Management International Review, 56(1), 67-94. doi:10.1007/s11575-015-0257-4

Hoejmose, S., Brammer, S., \& Millington, A. (2012). Green supply chain management: The role of trust and top management in B2B and B2C markets. Industrial Marketing Management, 41(4), 609-620. doi:10.1016/j. indmarman.2012.04.008

Hustad, E., \& Teigland, R. (2008). Implementing social networking media and web 2.0 in multinationals: Implications for knowledge management. Proceedings of the European Conference on Knowledge Management, 323-332.

Hutzschenreuter, T., Kleindienst, I., Guenther, C., \& Hammes, M. (2016). Speed of Internationalization of New Business Units: The Impact of Direct and Indirect Learning. Management International Review, 56(6), 849-878. doi:10.1007/s11575-016-0305-8 
Ibeh, K. \& Kasem, L. (2011). The network perspective and the internationalization of small and medium sized software firms from Syria. Industrial Marketing Management, 40(3), 358-367.

Ifinedo, P. (2011). Internet/e-business technologies acceptance in Canada's SMEs: An exploratory investigation. Internet Research, 21(3), 255-281. doi:10.1108/10662241111139309

Jarvis, C. B., MacKenzie, S. B., \& Podsakoff, P. M. (2003). A Critical Review of Construct Indicators and Measurement Model Misspecification in Marketing and Consumer Research. The Journal of Consumer Research, 30(2), 199-218. doi:10.1086/376806

Johanson, J., \& Vahlne, J. E. (1977). The internationalization process of the firm: A model of knowledge development and increasing foreign market commitments. Journal of International Business Studies, 8(1), 25-34. doi:10.1057/palgrave.jibs.8490676

Jones, M. V., Coviello, N., \& Tang, K. T. (2011). International entrepreneurship research (1989-2009): A domain ontology and thematic analysis. Journal of Business Venturing, 26(6), 632-659. doi:10.1016/j. jbusvent.2011.04.001

Jussila, J. J., Kärkkainen, H., \& Aramo-Immonen, H. (2014). Social media utilization in business-to-business relationships of technology industry firms. Computers in Human Behavior, 30, 606-613. doi:10.1016/j. chb.2013.07.047

Kananukul, C., Jung, S., \& Watchravesringkan, K. (2015). Building customer equity through trust in social networking sites A perspective from Thai consumers. Journal of Research in Interactive Marketing, 9(2), 148-166. doi:10.1108/JRIM-03-2014-0019

Kaplan, A. M., \& Haenlein, M. (2010). Users of the world, unite! The challenges and opportunities of social media. Business Horizons, 53(1), 59-68. doi:10.1016/j.bushor.2009.09.003

Keil, M., Tan, B. C., Wei, K. K., Saarinen, T., Tuunainen, V., \& Wassenaar, A. (2000). A cross-cultural study on escalation of commitment behavior in software projects. Management Information Systems Quarterly, 24(2), 299-325. doi:10.2307/3250940

Kietzman, J. H., Hermkens, K., McCarthy, I. P., \& Silvestre, B. S. (2011). Social media? Get serious! Understanding the functional building blocks of social media. Business Horizons, 54(3), 241-251. doi:10.1016/j. bushor.2011.01.005

Kim, S. S., \& Son, J.-Y. (2009). Out of Dedication or Constraint? A Dual Model of Post-Adoption Phenomena and Its Empirical Test in the Context of Online Services. Management Information Systems Quarterly, 33(1), 49-70. doi:10.2307/20650278

Kumar, V., \& Mirchandani, R. (2012). Increasing the ROI of Social Media Marketing. MIT Sloan Management Review, 54(1), 55-61.

Lado, N., Martínez-Ros, E., \& Valenzuela, A. (2004). Identifying successful marketing strategies by export regional destination. International Marketing Review, 21(6), 573-597. doi:10.1108/02651330410568024

Levenburg, N., Magal, S. R., \& Koslage, P. (2006). An exploratory investigation of organizational factors and e-Business motivations among SMFOEs in the US. Electronic Markets, 16(1), 70-84. doi:10.1080/10196780500491402

Lew, Y. K., \& Sinkovics, R. R. (2013). Crossing borders and industry sectors: Behavioral governance in strategic alliances and product innovation for competitive advantage. Long Range Planning, 46(1-2), 13-38. doi:10.1016/j.lrp.2012.09.006

Li, L., Qian, G., \& Qian, Z. (2015). Speed of internationalization: Mutual effects of individual- and companylevel antecedents. Global Strategy Journal, 5(4), 303-320. doi:10.1002/gsj.1103

Lorenzo-Romero, C., Constantinides, E., \& Alarcón-Del-Amo, M.-D.-C. (2013). Social media as marketing strategy: An explorative study on adoption and use by retailers. In C. Lorenzo-Romero, E. Constantinides, \& M.-D.-C. Alarcón-Del-Amo (Eds.), Social media in strategic management. Advanced series in management (pp. 197-215). Emerald.

Luo, Y., Zhao, J. H., \& Du, J. (2005). The internationalization speed of e- commerce companies: An empirical analysis. International Marketing Review, 22(6), 693-709. doi:10.1108/02651330510630294 
Majocchi, A., Bacchiocchi, E., \& Mayrhofer, U. (2005). Firm size, business experience and export intensity in SMEs: A longitudinal approach to complex relationships. International Business Review, 14(6), 719-738. doi:10.1016/j.ibusrev.2005.07.004

Mathews, S., Healy, M., \& Wickramasekera, R. (2012). The Internetalisation of information, knowledge, and interaction components of the firm's internationalisation process. Journal of Marketing Management, 28(5-6), 733-754. doi:10.1080/0267257X.2011.560887

Mathieson, K., Peacock, E., \& Chin, W. W. (2001). Extending the technology acceptance model: The influence of perceived user resources. The Data Base for Advances in Information Systems, 32(3), 86-112. doi:10.1145/506724.506730

Menon, A., Bharadwaj, S. G., \& Howell, R. (1996). The quality and effectiveness of marketing strategy: Effects of functional and dysfunctional conflict in intraorganizational relationships. Journal of the Academy of Marketing Science, 24(4), 299-313. doi:10.1177/0092070396244002

Michaelidou, N., Siamagka, N. T., \& Christodoulides, G. (2011). Usage, barriers and measurement of social media marketing: An exploratory investigation of small and medium B2B brands. Industrial Marketing Management, 40(7), 1153-1159. doi:10.1016/j.indmarman.2011.09.009

Moen, O. (1999). The relationship between firm size, competitive advantages and export performance revisited. International Small Business Journal, 18(1), 53-72. doi:10.1177/0266242699181003

Mohr, A., \& Batsakis, G. (2014). Intangible assets, international experience and the internationalisation speed of retailers. International Marketing Review, 31(6), 601-620. doi:10.1108/IMR-09-2013-0186

Mohr, A., \& Batsakis, G. (2014). Intangible assets, international experience and the internationalisation speed of retailers. International Marketing Review, 31(6), 601-620. doi:10.1108/IMR-09-2013-0186

Mohr, A., \& Batsakis, G. (2017). Internationalization Speed and Firm Performance: A Study of the MarketSeeking Expansion of Retail MNEs. Management International Review, 57(2), 153-177. doi:10.1007/s11575016-0284-9

Morgan, N. A., Kaleka, A., \& Katsikeas, C. S. (2004). Antecedents of Export Venture Performance: A Theoretical Model and Empirical Assessment. Journal of Marketing, 68(1), 90-108. doi:10.1509/jmkg.68.1.90.24028

Morgan-Thomas, A., \& Jones, M. V. (2009). Post-entry dynamics: Differences between SMEs in the development speed of their international sales. International Small Business Journal, 27(1), 71-97. doi: $10.1177 / 0266242608098347$

Musteen, M., Francis, J., \& Datta, D. K. (2010). The influence of international networks on internationalization speed and performance: A study of Czech SMEs. Journal of World Business, 45(3), 197-205. doi:10.1016/j. jwb.2009.12.003

Navarro-García, A., Arenas-Gaitán, J., \& Rondán-Cataluña, F. J. (2014). External environment and the moderating role of export market orientation. Journal of Business Research, 67(5), 740-745. doi:10.1016/j. jbusres.2013.11.037

Nazar, M. S., \& Saleem, H. M. N. (2009). Firm-Level Determinants of Export Performance. International Business \& Economics Research Journal, 8(2), 105-112.

Nurosis, M. J. (1993). SPSS. Statistical data analysis. SPSS Inc.

O’Reilly, T., \& Musser, J. (2007). Web 2.0 principles and best practices. O'Reilly Media, Inc.

OECD. (2018). Enterprises by business size (indicator). OECD. doi: 10.1787/31d5eeaf-en

Ojala, A. (2009). Internationalization of knowledge-intensive SMEs: The role of network relationships in the entry to a psychically distant market. International Business Review, 18(1), 50-59. doi:10.1016/j.ibusrev.2008.10.002

Okazaki, S., \& Taylor, C. R. (2013). Social media and international advertising: Theoretical challenges and future directions. International Marketing Review, 30(1), 56-71. doi:10.1108/02651331311298573 
Perrigot, R., Kacker, M., Basset, G., \& Cliquet, G. (2012). Antecedents of Early Adoption and Use of Social Media Networks for Stakeholder Communications: Evidence from Franchising. Journal of Small Business Management, 50(4), 539-565. doi:10.1111/j.1540-627X.2012.00366.x

Pezderka, N., Sinkovics, R. R., \& Jean, R. J. B. (2012). Do born global SMEs reap more benefits from ICT use than other internationalizing small firms? In M. Gabrielsson \& V. H. Manek Kirpalani (Eds.), Handbook of research on born globals (pp. 185-213). Cheltenham, UK: Edward Elgar. doi:10.4337/9780857938046.00021

Phan, M., Thomas, R., \& Heine, K. (2011). Social Media and Luxury Brand Management: The Case of Burberry. Journal of Global Fashion Marketing, 2(4), 213-222. doi:10.1080/20932685.2011.10593099

Pla-Barber, J., \& Alegre, J. (2007). Analysing the link between export intensity, innovation and firm size in a science-based industry. International Business Review, 16(3), 275-293. doi:10.1016/j.ibusrev.2007.02.005

Podsakoff, P. M., MacKenzie, S. B., Lee, J. Y., \& Podsakoff, N. P. (2003). Common Method Biases in Behavioural Research: A Critical Review of the Literature and Recommended Remedies. The Journal of Applied Psychology, 88(5), 879-903. doi:10.1037/0021-9010.88.5.879 PMID:14516251

Prasad, V. K., Ramamurthy, K., \& Naidu, G. M. (2001). The influence of Internet-Marketing Integration on Marketing Competencies and Export Performance. Journal of International Marketing, 9(4), 82-110. doi:10.1509/ jimk.9.4.82.19944

Rapp, A., Beitelspacher, L. S., Grewal, D., \& Hughes, D. E. (2013). Understanding social media effects across seller, retailer, and consumer interactions. Journal of the Academy of Marketing Science, 41(5), 547-566. doi:10.1007/s11747-013-0326-9

Rialp, A., Rialp, J., \& Knight, G. A. (2005). The phenomenon of early internationalizing firms: What do we know after a decade (1993-2003) of scientific inquiry? International Business Review, 14(2), 147-166. doi:10.1016/j. ibusrev.2004.04.006

Ringle, C. M., Wende, S., \& Will, A. (2005). SmartPLS (beta). Hamburg, Germany: University of Hamburg.

Saarenketo, S. K., Puumalainen, K., Kylaheiko, K., \& Kuivalainen, O. (2008). Linking knowledge and internationalization in small and medium-sized enterprises in the ICT sector. Technovation, 28(9), 591-601. doi:10.1016/j.technovation.2007.12.003

Swani, K., Brow, B. P., \& Milne, G. R. (2014). Should tweets differ for B2B and B2C? An analysis of Fortune 500 companies' Twitter communications. Industrial Marketing Management, 43(5), 873-881. doi:10.1016/j. indmarman.2014.04.012

Taylor, D. G., Lewin, J. E., \& Strutton, D. (2011). Friends, fans, and followers: Do ads work on social networks? How gender and age shape receptivity. Journal of Advertising Research, 51(1), 258-275. doi:10.2501/JAR-51$1-258-275$

Teo, T. S. H. (2007). Organizational characteristics, modes of Internet adoption and their impact: A Singapore Perspective. Journal of Global Information Management, 15(2), 91-117. doi:10.4018/jgim.2007040104

Terblanche, N. S., \& Boshoff, C. (2008). Improved scale development in marketing: An empirical illustration. International Journal of Market Research, 50(1), 105-119. doi:10.1177/147078530805000108

Verwaal, E., \& Donkers, B. (2002). Firm Size and Export Intensity: Solving an Empirical Puzzle. Journal of International Business Studies, 33(3), 603-613. doi:10.1057/palgrave.jibs.8491035

Wetzels, M., Oderkerken-Schröder, G., \& van Oppen, C. (2009). Using PLS path modeling for assessing hierarchical construct models: Guidelines and empirical illustration. Management Information Systems Quarterly, 33(1), 177-195. doi:10.2307/20650284

Wiersema, F. (2013). The B2B agenda: The current state of B2B marketing and a look ahead. Industrial Marketing Management, 42(4), 470-488. doi:10.1016/j.indmarman.2013.02.015

Williams, D. A. (2011). Impact of firm size and age on the export behaviour of small locally owned firms: Fresh insights. Journal of International Entrepreneurship, 9(2), 152-174. doi:10.1007/s10843-011-0073-2 
Zhang, M., Sarker, S., \& Sarker, S. (2013). Drivers and export performance impacts of IT capability in 'bornglobal' firms: A cross-national study. Information Systems Journal, 23(5), 419-443. doi:10.1111/j.13652575.2012.00404.x

\section{ENDNOTE}

1 Admitting that the studied relation could be reversed (the speed of internationalization could impact on the speed of use of social media), we replicated all the analysis changing the direction of the relationship among both constructs. The relationship was not significant (the coefficient was 0.023 , with a significance level $=0.628(\mathrm{t}$ value $=0.485)$, what supports the direction of the relationship suggested in the current research.

Josep Rialp is Associate Professor in Marketing and Market Research in the Department of Business of Universitat Autònoma de Barcelona, Spain. He is author and/or co-author of different books, chapter books or papers is both national and international academic journals such as International Business Review, Advances in International Marketing, Journal of World Business, Regional Studies, Journal of Advertising, Journal of Business Research and Journal of Small Business Management, among others. His research interests are: SMEs' internationalization, international marketing, marketing metrics, interorganizational collaboration, and research techniques. Dr Josep Rialp also serves as associate editor in Cuadernos de Economía y Dirección de la Empresa as well as ad-hoc reviewer for different academic journals.

María-del-Carmen Alarcón-del-Amo is assistant professor in the University of Murcia. She is author and/or co-author of different journals, such as European Management Journal, International Business Review, Internet Research, Cyberpsychology, Behavior and Social Networking, International Journal of Market Research, Higher Education, Current Issues on Tourism, among others, and several book chapters about Social Media and Management in Springer and Emeral editorial. Her main research line is focused on the analysis of online consumer behaviour in the context of social networking sites, electronic commerce and Web 2.0, and utilization of social media by small and medium enterprises. Due to her research work, she has received several awards: CajaMurcia research award, Junior AEDEMO (Spanish Association of Market Research, Marketing and Opinion) Award, and second QUANDO Young Research Award for the Doctoral Dissertation.

Alex Rialp-Criado is an Associate professor at Universitat Autònoma de Barcelona (UAB), Spain, and Adjunct Professor at the Norwegian University of Science and Technology (NTNU). His research covers international business/marketing and international entrepreneurship, with a focus on the internationalization of new ventures and established small and medium-sized enterprises. He is authors and/or co-author of different books, chapter books, and articles in leading international academic journals in these fields such as International Business Review, Management International Review, Journal of World Business, Journal of International Marketing, International Marketing Review, Advances in International Marketing, Journal of Small Business Management, Entrepreneurship and Regional Development, European Management Journal, Journal of International Entrepreneurship, Critical Perspectives on International Business, among others. Dr Alex Rialp also serves as editorial board member of International Business Review and Journal of International Entrepreneurship as well as ad-hoc reviewer for different academic journals. 